\title{
Effects of the Level of Dietary Rice Bran with or without Phytase, on Performance and Egg Parameters of Laying Japanese Quail
}

\author{
H.M.W.N. Abeyrathna, N.S.B.M. Atapattu ${ }^{1 *}$ and W.W.D.A. Gunawardane ${ }^{1}$ \\ Advanced Technological Institute \\ Labuduwa, Galle \\ Sri Lanka
}

\begin{abstract}
Cost of quail feed formulations can be reduced substantially by using cheap cereal by-products such as rice bran $(R B)$ at higher levels. The objective of this study was to determine the maximum inclusion levels of dietary $R B$ with or without exogenous phytase, for laying Japanese quail. In a completely randomized design with a $3 \times 2$ factorial arrangement, 108 quails in 36 cages received six experimental diets ad libitum from 8 to 15 week. Experimental factors were three dietary RB inclusion levels (20, 30 and 40\%) and two phytase levels (0 and $1000 \mathrm{FTU} / \mathrm{kg})$. The level of dietary RB, phytase supplementation and their interaction had no significant effects on live weight or feed intake. The total egg production of the quail fed 40\% RB was significantly lower than that of quail fed 20 and $30 \%$ RB. Egg laying rate of the quail fed $40 \%$ RB was significantly lower than those of the quail fed 20 or $30 \%$ RB from $6^{\text {th }}$ week onwards. By eighth week, $30 \%$ RB resulted in significantly lower egg laying rate compared to the quail fed $20 \%$ RB. Feed conversion ratio (FCR) of the quail fed $40 \% R B$ was significantly higher than those of 20 or $30 \% R B$ fed. Adverse effects of phytate in 30 or $40 \%$ RB on egg number, egg mass and FCR were not mitigated by the supplemental phytase. It is concluded that inclusion of more than $20 \%$ RB in the diets of laying Japanese quail reduces the production performances.
\end{abstract}

Keywords: Egg, feed, performance, quail, rice bran

\section{INTRODUCTION}

Japanese quail is an important poultry species reared for meat and eggs and as a laboratory model (Siyadati et al., 2011). Feed cost accounts for more than $70 \%$ of the total recurrent cost of production and thus greatly influences the profitability of quail production and the affordability of meat or eggs to consumers. In order to reduce the cost of feed formulations, it is important to use cheap, locally available agricultural by-products such as rice bran. The in vitro nutritive value of $\mathrm{RB}$ is superior to or at least comparable with other cereal by products (Farrell, 1994). In areas where rice is grown, RB is a cheap feed ingredient and thus the unit costs of many nutrients and energy are lower than those of other cereals and their byproducts. Oladunjoye and Ojebiyi (2010) found that the feeding cost of broilers given diets with $20 \% \mathrm{RB}$ was significantly lower than those fed $10 \% \mathrm{RB}$. Therefore, strategies to increase the usability of RB in quail diets are of importance. Only a limited number of studies have been conducted to evaluate the feeding value of RB for Japanese quail. Performance of meat (Attia et al., 2006; Ismail et al., 2006) and layer (Aggoor et al., 2006;

1 Department of Animal Science, Faculty of Agriculture, University of Ruhuna, Mapalana, Kamburupitiya, Sri Lanka.

Corresponding author: mahindaatapattu@gmail.com 
Amoah and Martin, 2010) type quail fed 20\% full fat RB was comparable with those fed $0 \%$ RB. Bhanja and Verma (2001) fed diets containing 10, 20 and 30\% de-oiled RB to layer quail and concluded $20 \%$ to be the maximum inclusion level for defatted RB.

Studies with other poultry species have shown that layer chickens and ducks can tolerate as high as $40 \%$ dietary RB while broilers can tolerate a maximum of $20 \%$ (Farrell, 1994). These differences may be attributed to the extent to which respective species/type of poultry can tolerate the anti-nutrients such as phytate, fibre, anti-proteolytic substances and lipase present in RB. No attempt has been made to test the possibility of using higher than $20 \%$ full fat RB in quail diets. Positive effects of exogenous phytase on phosphorus $(\mathrm{P})$, energy and protein utilization efficiencies are well documented (Woyengo et al., 2011). Since phytate is among the main anti-nutrients that reduce the in vivo nutritive value of RB (Farrell, 1994), it was hypothesized that maximum inclusion levels of RB in Japanese quail diets could be increased by phytase supplementation. The objective of this study was to determine the maximum inclusion levels of dietary RB, with or without phytase in laying Japanese quail diets.

\section{MATERIALS AND METHODS}

4-week-old female Japanese quail $(n=108)$ were allocated into 36 cages arranged in three tiers. For three weeks of the acclimatization period, birds were fed commercial grower crumbles. At the end of the seventh week of age, birds were weighed and cages were randomly allocated into 6 dietary treatments so that among cages live weight variation was minimum. The experiment followed a complete randomized design with a 3 x 2 factorial arrangement. Treatment factors were three dietary RB levels (20, 30 or $40 \%)$ and two phytase (Phytazag, Zagro, Singapore) levels (0 or 1000 FTU/kg). Each treatment combination had six replicate cages, each holding three birds. All diets met the nutrient requirements of Japanese quail as set out by NRC (1994). Ingredient composition and calculated nutrient composition of the experimental diets are given in Table 1.

Birds were given experimental diets and water ad libitum for eight weeks from the $8^{\text {th }}$ to $15^{\text {th }}$ week. Daily feed and water intake, egg production and egg weights and live weights of the birds after 2, 4, 6 and 8 weeks from the start of treatment were recorded. Feed conversion ratio was defined as feed intake/total egg mass. Two eggs randomly collected from each cage after 2, 4, 6, and 8 weeks of treatment imposition were used to determine egg component weights and yolk cholesterol contents. After taking the weight, length and width, the eggs were broken and opened. The yolk was gently separated from the albumin, adherent albumin was removed by rolling the yolk over a tissue paper, and the yolk fresh weight was recorded. The yolk and albumin were then dried at $105{ }^{\circ} \mathrm{C}$ for three days to get the dry weights of the respective components.

The fresh weight of the albumin was calculated as egg weight - (shell weight + yolk weight). Shells were air dried for three days and then oven dried at $65{ }^{\circ} \mathrm{C}$ for three days to get shell weight. Oven dried shells were ashed at $550{ }^{0} \mathrm{C}$ for 12 hours to determine the shell ash content. Shape index was calculated as; Shape index = maximum width/maximum length $\mathrm{x}$ 100. Shell thickness was measured using an egg shell thickness meter (Orawa, Seiki, Japan). Yolk cholesterol contents were determined as described by Lien et al. (2012) using a commercial cholesterol assay kit (SPINREACT, S.A. Ctra, Santa Coloma, Spain). Latency to lie times for one randomly selected birds from each cage were determined on $8^{\text {th }}$ week, as described by Bailie et al. (2012). 
Data were analyzed using SAS (1985). Main effects were compared using the Duncon's Multiple Range Test procedure while interactions were compared using the Least Square (LS) mean comparison procedure.

Table1. Ingredient composition and nutrient composition of the experimental diets

\begin{tabular}{lccc}
\hline Ingredient & \multicolumn{3}{c}{ Dietary rice bran levels (\%) } \\
& $\mathbf{2 0}$ & $\mathbf{3 0}$ & $\mathbf{4 0}$ \\
\hline Maize meal (\%) & 38.2 & 29.3 & 21.8 \\
Rice bran (\%) & 20 & 30 & 40 \\
Soya bean meal (\%) & 28 & 26.5 & 23.3 \\
Coconut oil (\%) & 3.5 & 3.9 & 3.9 \\
Fish meal (\%) & 3.4 & 3.4 & 4.3 \\
Dicalcium phosphate (\%) & 1.1 & 1 & 0.9 \\
Shell powder (\%) & 5.3 & 5.4 & 5.3 \\
Salt (\%) & 0.25 & 0.25 & 0.25 \\
Vitamin mineral mix (\%) & 0.25 & 0.25 & 0.25 \\
Phytase & $-/+$ & $-/+$ & $-/+$ \\
Price (Rs/Kg) & $79.74 / 79.76$ & $76.92 / 76.94$ & $75.51 / 75.53$ \\
& & & \\
Nutrient composition & & & \\
Energy (Kcal/kg) & 2900 & 2900 & 2900 \\
CP (\%) & 20 & 20 & 20 \\
Non phyate P (\%) & 0.35 & 0.35 & 0.35 \\
Ca (\%) & 2.5 & 2.5 & 2.5 \\
Lysine (\%) & 1.1 & 1.1 & 1.1 \\
Methionine + Cystine (\%) & 0.7 & 0.7 & 0.7 \\
Crude fibre (\%) & 5.1 & 5.9 & 6.3 \\
\hline
\end{tabular}

\section{RESULTS}

Inclusion of $40 \%(75.52 \mathrm{Rs} / \mathrm{kg})$ or $30 \%(76.93 \mathrm{Rs} / \mathrm{kg}) \mathrm{RB}$ lowered cost of feed formulations compared to the diet having $20 \% \mathrm{RB}$ (79.75 Rs), whereas supplemental phytase incurred only 2 cents of an additional cost per $\mathrm{kg}(79.74$ vs $79.76 \mathrm{Rs} / \mathrm{kg}$ ) (Table 1). The level of dietary RB, supplemental phytase and their interaction had no significant effects on live weights or feed intake of the birds (Table 2). The total egg production of the quail fed $40 \%$ dietary RB (35) was significantly lower than that of birds fed $20 \%$ (43) and $30 \%$ (40) RB (Table 3). Negative effect of $40 \% \mathrm{RB}$ on egg laying rate commenced as early as $3^{\text {rd }}$ week of feeding (Fig 1). Laying rate of the quail fed $40 \%$ RB declined sharply after five weeks of feeding and was significantly lower than those of the quail fed 20 or $30 \%$ RB from $6^{\text {th }}$ week onwards. By $8^{\text {th }}$ week, $30 \%$ dietary RB resulted in significantly lower egg laying rate compared to the quail fed $20 \%$ RB. The FCR of the birds fed $40 \%$ RB (5.6) was significantly higher than those of 20 (4.7) or $30 \%$ (5.1) RB fed birds. The negative effects of $40 \%$ RB on FCR commenced from $5^{\text {th }}$ week onward and became significant by $7^{\text {th }}$ week (Fig. 2). Poor FCR was evident in $30 \% \mathrm{RB}$ compared to $20 \% \mathrm{RB}$ on $8^{\text {th }}$ week. 
Table 2. Effects of three dietary RB levels and phytase supplementation on live weight and feed consumption parameters of laying Japanese quail

\begin{tabular}{|c|c|c|c|c|c|c|c|c|c|c|}
\hline \multirow{2}{*}{$\begin{array}{l}\text { RB level (\%) } \\
\text { Phytase }\end{array}$} & \multirow{2}{*}{$\begin{array}{l}20 \\
-\end{array}$} & \multirow{2}{*}{$\begin{array}{l}20 \\
+\end{array}$} & \multirow{2}{*}{$\begin{array}{l}30 \\
-\end{array}$} & \multirow{2}{*}{$\begin{array}{l}30 \\
+\end{array}$} & \multirow{2}{*}{$\begin{array}{l}40 \\
-\end{array}$} & \multirow{2}{*}{$\begin{array}{l}40 \\
+\end{array}$} & \multirow{2}{*}{ SEM } & \multicolumn{3}{|c|}{ Effect } \\
\hline & & & & & & & & $\mathbf{R B}$ & $\mathbf{E}$ & $\mathbf{R B} * \mathbf{E}$ \\
\hline \multicolumn{11}{|c|}{ Live weight (g) (weeks after treatment imposition) } \\
\hline 0 week & 181 & 179 & 175 & 183 & 167 & 185 & 14 & NS & NS & NS \\
\hline $8^{\text {th }}$ week & 204 & 188 & 184 & 189 & 204 & 183 & 8 & NS & NS & NS \\
\hline Feed intake $^{1}$ & 35.4 & 35.7 & 35.8 & 35.5 & 35.8 & 35.8 & 0.46 & NS & NS & NS \\
\hline FCR & 5.1 & 4.2 & 4.8 & 5.4 & 5.6 & 5.6 & 0.8 & $*$ & NS & NS \\
\hline Feed cost (Rs) & 158 & 160 & 155 & 153 & 152 & 152 & 2 & $* *$ & $\mathrm{NS}$ & NS \\
\hline $\begin{array}{l}\text { Feed cost } / \mathrm{kg} \\
\text { egg mass }\end{array}$ & 408 & 341 & 369 & 422 & 423 & 444 & 69 & NS & NS & NS \\
\hline
\end{tabular}

Table 3. Effects of three dietary RB levels and phytase supplementation on egg production and relative weights of egg components of laying Japanese quail

\begin{tabular}{|c|c|c|c|c|c|c|c|c|c|c|}
\hline \multirow{2}{*}{$\begin{array}{l}\text { RB level (\%) } \\
\text { Phytase }\end{array}$} & \multirow{2}{*}{$\begin{array}{c}20 \\
-\end{array}$} & \multirow{2}{*}{$\begin{array}{c}20 \\
+\end{array}$} & \multirow{2}{*}{$\begin{array}{c}30 \\
-\end{array}$} & \multirow{2}{*}{$\begin{array}{c}30 \\
+\end{array}$} & \multirow{2}{*}{$\begin{array}{c}40 \\
-\end{array}$} & \multirow{2}{*}{$\begin{array}{c}40 \\
+ \\
\end{array}$} & \multirow[t]{2}{*}{ SEM } & \multicolumn{3}{|c|}{ Effect } \\
\hline & & & & & & & & RB & $\mathbf{E}$ & $\mathbf{R B} * \mathbf{E}$ \\
\hline $\begin{array}{l}\text { Total no of } \\
\text { eggs/ bird }\end{array}$ & 40 & 47 & 44 & 38 & 36 & 34 & 6.2 & * & NS & NS \\
\hline $\begin{array}{l}\text { Total egg } \\
\text { mass }(\mathrm{g})\end{array}$ & 401 & 469 & 428 & 384 & 359 & 345 & 62 & $* *$ & NS & NS \\
\hline \multicolumn{11}{|l|}{ Egg weight (g) } \\
\hline Week 8 & 10.4 & 9.6 & 9.8 & 10.5 & 9.8 & 9.8 & 0.63 & NS & NS & * \\
\hline \multicolumn{11}{|c|}{ Egg components } \\
\hline Yolk (\%) & 32.2 & 30.9 & 32.7 & 32.9 & 32 & 32.9 & 1.6 & NS & NS & NS \\
\hline Albumin (\%) & 60.2 & 60.8 & 58.9 & 59.3 & 60 & 60.3 & 1.7 & NS & NS & NS \\
\hline Shell (\%) & 7.5 & 8.2 & 8.2 & 7.7 & 7.8 & 7.7 & 0.6 & NS & NS & NS \\
\hline Shell ash (\%) & 70 & 61 & 64 & 60 & 54 & 75 & 7 & NS & NS & NS \\
\hline $\begin{array}{l}\text { Shell thickness } \\
\text { (mm) }\end{array}$ & 0.31 & 0.31 & 0.31 & 0.29 & 0.29 & 0.31 & 0 & NS & NS & NS \\
\hline Shape index & 85 & 82 & 81 & 78 & 85 & 85 & 5.9 & NS & NS & NS \\
\hline
\end{tabular}

NS; $\mathrm{P}>0.05, * ; \mathrm{P}<0.05, * * ; \mathrm{P}<0.01$

E; Enzyme

Effect of dietary treatments on egg weight was erratic. In the $4^{\text {th }}$ week, 20\% $(10.2 \mathrm{~g})$ and $40 \%$ (9.7 g) RB resulted in significantly heavier eggs than 30\% RB (9.0 g). Meanwhile, supplemental enzyme produced heavier eggs in the $4^{\text {th }}$ and $6^{\text {th }}$ week. There was a significant RB x phytase enzyme interactive effect on egg weight in week eight, where phytase 
supplementation significantly reduced the egg weight at the $20 \% \mathrm{RB}$ level but had no effect at 30 or $40 \%$ RB levels.

Reduction in feed cost was observed when dietary RB level increased from 20 (159 Rs), through 30 (154 Rs) to $40 \%$ (152 Rs). However, feed costs per kg of egg mass production of the quail fed 30 (395.5 Rs) or 40\% (433.5 Rs) were higher than those fed $20 \%$ RB $(374.5$ RS). The negative effects of higher RB on financial returns were also not corrected by phytase.

Percentage egg component weights were not significantly affected by the treatments (Table 3). Egg yolk cholesterol contents and the latency to lie times were also not affected by treatment (Table 4).

Table 4. Effects of three dietary RB levels and phytase supplementation on yolk cholesterol level and latency to lie (min) of laying Japanese quail

\begin{tabular}{lcccccccccc}
\hline $\begin{array}{l}\text { RB level (\%) } \\
\text { Phytase }\end{array}$ & $\mathbf{2 0}$ & $\mathbf{2 0}$ & $\mathbf{3 0}$ & $\mathbf{3 0}$ & $\mathbf{4 0}$ & $\mathbf{4 0}$ & SEM & \multicolumn{3}{c}{ Effect } \\
\hline $\begin{array}{l}\text { Cholesterol } \\
\text { (mg/g dry }\end{array}$ & 11.8 & 11.4 & 11.4 & 12.7 & 12.5 & 12.1 & 0.48 & NS & NS & NS \\
yolk) & & & & & & & & & & \\
$\begin{array}{l}\text { Latency to lie } \\
\text { (min) }\end{array}$ & 209 & 229 & 225 & 219 & 217 & 207 & 21 & NS & NS & NS \\
\hline
\end{tabular}

$\mathrm{NS} ; \mathrm{P}>0.05$

E; Enzyme

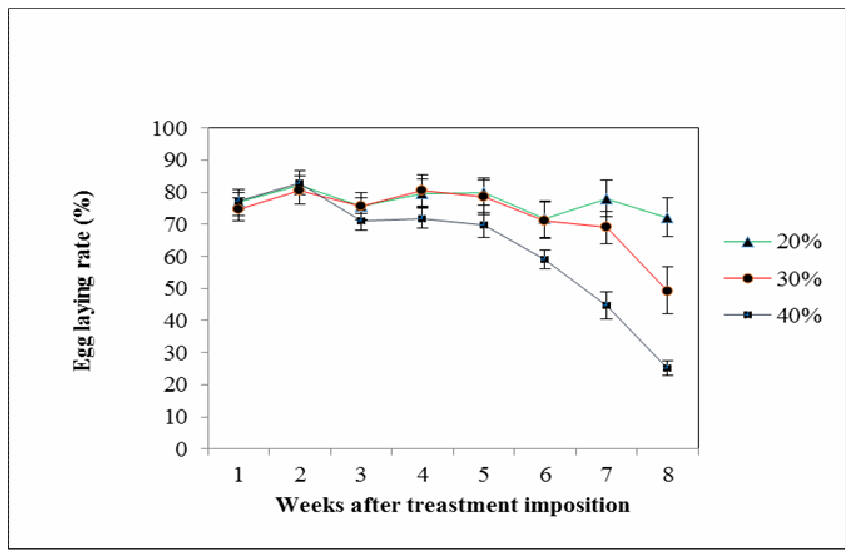

Fig. 1. Effects of dietary rice bran levels on egg laying rate of laying Japanese quail 


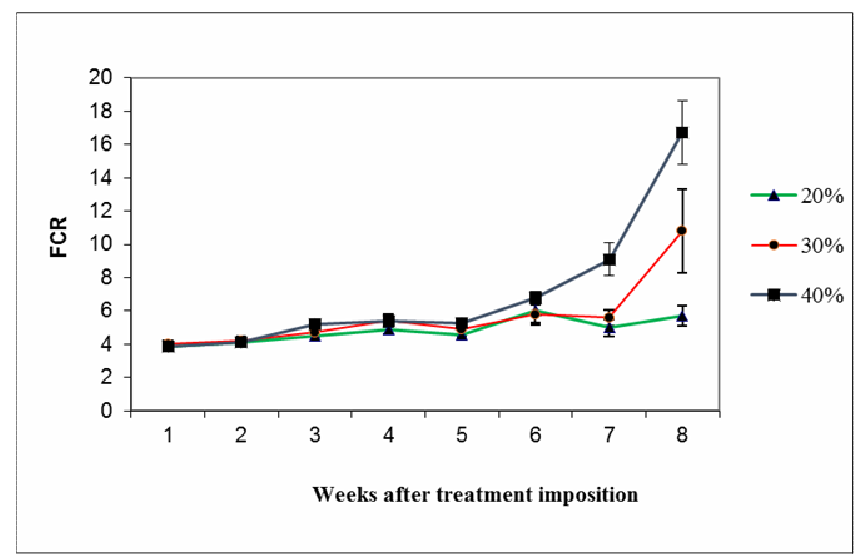

Fig 2. Effects of dietary rice bran levels on feed conversion ratio of laying Japanese
quail

\section{DISCUSSION}

Attia et al. ( 2006) showed that feed intake of quail fed a diet with 20\% RB from 14-42 days was lower than that of the birds fed RB free control diet. Bhanja and Verma (2001) found no significant difference in feed intakes and weight gains of quail fed 10, 20 or $30 \%$ de-oiled rice bran. The latter study has also reported that the nutrient utilization efficiencies of older Japanese quail (10 weeks old) were significantly better than those younger counterparts (6 weeks old). It is suggested that relatively mature birds used in this experiment could tolerate higher levels of RB without feed intake and live weight being negatively affected.

Inferior laying performance of the quail fed 30 or $40 \% \mathrm{RB}$ indicates that utilization efficiency of ingested nutrients has been reduced. Furthermore, the resulting adverse effects on production parameters could not be mitigated by supplemental phytase. It has been well established that anti-nutrients such as phytate, fibre, anti-proteolytic substances present in $\mathrm{RB}$ reduced in vivo protein, energy and mineral value of the diets and thereby the performance of poultry (Farrell, 1994). Therefore, it is hypothesized that an integrated approach/es aiming many or all anti-nutrients simultaneously is/are needed to increase the level of RB in quail feeds. This hypothesis is supported by the findings of Attia et al. (2003) that the RB level could be increased up to $30 \%$ when a broiler diet formulated on available amino acid levels is supplemented simultaneously with phytase and phospholipase.

Lack of positive response to supplemental phytase on the shell thickness, shell ash content and the latency to lie may be due to the use of an adequate level of dietary Non Phytate Phosphorus (NPP) level. As in the present experiment, supplementation of a quail diet having $0.3 \%$ (Vali and Jalali, 2010) and $0.35 \%$ (Sacakli et al., 2006) of NPP with phytase has not improved growth performance, carcass yield, percentage of tibia ash or tibia phosphorus of Japanese quail.

Significant reduction in feed cost observed with increasing dietary RB levels reflects the lower feed formulation costs of the respective diets. Indicating the negative effects of higher RB levels on financial returns, feed costs per $\mathrm{kg}$ of egg mass production of the quail fed $40 \%$ or $30 \%$ were 15.6 and $5.4 \%$ higher, compared to those fed $20 \%$ RB. Even though the 
negative effects of higher RB (30 and 40\%) on financial returns were also not corrected by phytase, the lowest feed cost per kg of egg mass production was recorded by the quail fed $20 \%$ RB with phytase supplementation.

Interestingly, increasing RB levels had negative effects on egg production parameters, but not on egg quality parameters such as shell thickness and shell ash and on bone status as determined by the latency-to-lie. In line with our findings, it has been reported that increase of RB level up to $10 \%$ (Nobakht, 2007) or 15\% (Samli et al., 2006) reduced the egg production parameters but not the egg quality traits of layer chicken. Contrary to the findings of the study, Gallinger et al. (2004) reported that increasing RB level from 0-40\% with $0.67 \%$ available $\mathrm{P}$, significantly reduced the mineral status of laying hens. Results of the present experiment suggest that adverse effects of high RB levels on mineral utilization efficiency in quail may not be as strong as in layer chicken. Differences in phosphorus utilization efficiency among species, as shown by Rodehutscord and Dieckmann (2005) and lower maintenance P requirements of quail may be the reasons for such variations.

Egg component weights were comparable with values reported by Aggroor et al. (2006). The same research also reported that dietary RB did not change the relative proportions of the egg components. Cholesterol values reported in this study were similar to those reported by Bragagnolo and Rodriguez-Amaya (2003). Even though a number of human (Prasad, 2011; Lai et al., 2012; Mäkynen et al., 2012) and animal (Mobarak et al., 2010) studies have shown that RB and RB oil have hypocholesterolemic effects, results of this experiment suggest that such an effect does not exist in quail.

\section{CONCLUSION}

It is concluded that the inclusion of more than $20 \% \mathrm{RB}$ in laying Japanese quail diets reduces the production performance. Supplemental phytase does not mitigate the adverse effects of high RB levels on the production performance of laying Japanese quail.

\section{ACKNOWLEDGEMENT}

Prof J.M. Forbes, University of Leeds, UK for his comments on the draft. Mr. P.K. Lal and Mr Kapila Premakumara for their excellent technical support. University of Ruhuna, Sri Lanka for providing financial assistance Advanced Technological Institute, Labuduwa, Galle, Sri Lanka for providing experimental cage facilities and Quail birds.

\section{REFERENCES}

Aggoor, F.A.M., Attia, Y.A., Ismail, F.S A., Qota, E.M A. and Shakmak, E.A. (2006). Effect of level and source of dietary energy and/or enzyme additions on productive performance and egg quality of Japanese quail hens. EPC 2006 XII European Poultry Conference, Verona, Italy, 10-14 Sep. 2006.

Amoah, J.K. and Martin, E.A. (2010). Quail (Coturnix coturnix japonica) layer diets based on rice bran and total or digestible amino acids, J Appl Biosci, 26, 1647 - 1652. 
Attia, Y.A., Aggoor, F.A.M., Ismail, F.S.A., Qota, E.M A. and Shakmak, E.A. (2006). Effect of energy level, rice by products and enzyme additions on growth performance and energy utilization of Japanese quail. EPC 2006 XII European Poultry Conference, Verona, Italy, 1014 Sep. 2006.

Attia, Y.A., Qota, E.M.A., Aggoor, F.A.M. and Kies, A.K. (2003). Value for rice bran, its maximal utilisation and its upgrading by phytase and other enzymes and diet-formulation based on available amino acids in the diet for broilers. Archiv für Geflügelkunde. 67(4), 157 $-166$

Bailie, C.L., Ball, M.E.E. and O'Connell, N.E. (2012). Influence of the provision of natural light and straw bales on activity levels and leg health in commercial broiler chickens. Animal: Int $\mathrm{j}$ of animal biosci, $1,1-9$

Bhanja, S.K. and Verma, S.V.S.D. (2001). Potential feeding value of deoiled rice bran by Japanese quails: Effects on nutrient utilization. Asian Australian Journal of Animal Science $14,1144-1148$

Bragagnolo, N. and Rodriguez-Amaya, D.B. (2003). Comparison of the Cholesterol content of Brazilian chicken and quaileggs. Journal of Food Composition and Analysis, 16(2), 147 153.

Farrell, D.J. (1994). Utilization of rice bran in diets for domestic fowl and ducklings. World Poultry Science J. 5, 116 - 131.

Gallinger, C.I., Suárez, D.M. and Irazusta, A. (2004). Effects of rice bran inclusion on performance and bone mineralization in broiler chicks. J Applied Poult Res, 13(2), 183 190.

Ismail, F.S.A., Attia, Y.A., Aggoor, F.A.M., Qota, E.M.A. and Shakmak, E.A. (2006). Effect of energy level, rice by products and enzyme additions on carcass yield, meat quality and plasma constituents of Japanese quail. EPC 2006 XII European Poultry Conference, Verona, Italy, 10-14 Sep. 2006.

Lai, M.H., Chen, Y.T., Chen,Y.Y., Chang, J.H. and Cheng, H.H. (2012). Effects of rice bran oil on the blood lipids profiles and insulin resistance in type 2 diabetes patients. $\mathrm{J}$ Cli Biochem and Nutri, 51(1), 15 - 18.

Lien, T.F, Cheng, Y.H. and Wu Y.P. (2012). Effects of supplemental bromelain on egg production and quality, serum and liver traits of laying hens. J Anim Sci Adv, 2(4), 386 391.

Mäkynen, K., Chitchumroonchokchai, C., Adisakwattana, S., Failla, M. and Ariyapitipun,T. (2012). Effect of gamma-oryzanol on the bioaccessibility and synthesis of cholesterol. Eur Rev Med Pharmacol Sci, 16(1), 49 - 56.

Mobarak, E.A., El-Shazly, A.S. and Barakat, A.S. (2010). Effect of supplementing balady bread with rice bran on the high blood glucose and cholesterol levels. Mansoura University Journal of food and dairy Sciences, 1(5), 253 - 266 
Nobakht, A. (2007). The effects of inclusion different levels of rice bran in laying hens diets on performance and plasma and egg yolk cholesterol contents. J Anim. Vet Adv, 6(9), 1120 1124.

NRC. (1994). Nutrient Requirements of Poultry. National Research Council. National Academy of Science, Washington, D.C.

Oladunjoye, I.O. and Ojebiyi, O.O. (2010). Performance Characteristics of Broiler Chicken (Gallus gallus) Fed Rice (Oriza sativa) Bran with or Without Roxazyme G2G. International Journal of Animal and Veterinary Advances 2(4), 135 - 140.

Prasad, M.N. (2011). Health benefits of rice bran-A Review. J Nutri Food Sci, 1,108.

Rodehutscord, M. and Dieckmann, A. (2005). Comparative studies with three-week-old chickens, turkeys, ducks, and quails on the response in phosphorus utilization to a supplementation of monobasic calcium phosphate Poult Sci, 84, 1252 - 1260

Sacakli, P., Sehu, A., Ergilin, A., Genc, B. and Selcuk, Z. (2006). The effect of phytase and organic acid on growth performance, carcass yield and tibia ash in quails fed diets with low levels of non-phytate phosphorusAustralian Asian Journal of Animal Science 19, 198 - 202.

Samli, E.H., Senkoylu, N., Akyurek, H.and Agma, A. (2006). Using rice bran in laying hen diets. J Central Europ Agric, 7(1), 135 - 140.

SAS Institute (1985). SAS User Guide. SAS Inc, Cary NC.

Siyadati, S,, Irani,M., Ghazvinian, K., Aghsaghali, A.M., Rezaipoor, V., Fath, H., Alipoor, K. and Ghavidel,S.Z. (2011). Effect of varying dietary energy to protein ratio on productive performance and carcass characteristics of Japanese quail. Annals Biol Res, 2(1), 149 - 155.

Vali, N. and Jalali, M.A. (2010). Influence of Different Levels of Phytase Enzyme on Japanese quail (Coturnix japonica) Performance. Agriculturae Conspectus Scientifi cus, 76 (4), 387 - 390.

Woyengo, T.A. and Nyachoti, C.M. (2011). Review: Supplementation of phytase and carbohydrases to diets for poultry. Canad J of Anim Sci, 91(2), 177 - 192. 